\title{
Cardiovascular disease and genetics of the renin-angiotensin system
}

\author{
Stephen B Harrap
}

From its origins in renal physiology, the reninangiotensin system has established its functional and pathological significance for many organs. For cardiovascular tissues, both circulating and tissue components of this system appear to be relevant. Changes in its activity have been associated with important effects on the normal and diseased circulation. ${ }^{12}$ Therapeutic interference with the system is of proven benefit in hypertension, cardiac hypertrophy, following myocardial infarction, and in heart failure. ${ }^{3-5}$ Therefore it is not surprising that genes associated with the reninangiotensin system are popular candidates for the investigation.

Genetics of the renin-angiotensin system The discovery of the genes that encode renin, angiotensinogen, angiotensin converting enzyme (ACE), and angiotensin receptors has made genetic analysis a reality. Certain molecular markers reveal genetic variation between individuals which, in the case of angiotensinogen and ACE genes, are associated with significant differences in the activity of the renin-angiotensin system. These functional correlations may be relevant to normal physiological variation or cardiovascular disease, particularly where familial predisposition is evident.

Molecular tests are now so widely available that studies of the genetics of cardiovascular disease is a growth industry. In contrast to biochemical or physiological characteristics, genetic markers are constant, qualitative, and not confounded by the complications of disease or the effects of treatment. Thousands of genetic tests can be performed on a single blood sample, and new methods deal efficiently with many samples. ${ }^{6}$ The design of contemporary clinical trials, population surveys, and case-control studies often includes blood taken for future genetic analysis. We must remember, however, that the technological wizardry of molecular biology does not absolve investigators of the responsibilities for good research design.

The potential benefit from understanding the genetics of cardiovascular disease is remarkable $^{7}$ and the genes of the reninangiotensin system have been an area of con-

\section{Glossary of trials}

ECTIM - Etude Cas-Témoins de l'Infarctus du Myocarde siderable activity (figure). Clear answers have not yet crystallised and the task is far from simple. $^{8}$

THE RENIN GENE

A logical contender for hypertension since the Goldblatt era, the renin gene was among the first genes to be cloned. However, available markers of the gene have not been linked with cardiovascular disease $\mathrm{e}^{9-11}$ and interest has waned. Nevertheless, existing renin gene markers probably reflect a small amount of the individual variation in DNA in and around this gene. An important role for the renin gene cannot be discounted and new informative markers may rekindle interest.

THE ANGIOTENSINOGEN GENE

A better genetic prospect has been the angiotensinogen gene. Hypertension is of particular interest, as high angiotensinogen concentrations are found in young people with genetic predisposition to high blood pressure. ${ }^{12}$ The angiotensinogen gene has been linked in family studies with hypertension, and DNA variants associated with increased plasma angiotensinogen are found more commonly in hypertensive than normotensive individuals. ${ }^{13}$ Importantly, these relations have been largely confirmed in a variety of independent populations. ${ }^{14-17}$ However, two other studies have not shown any such links. ${ }^{18} 19$ There also appears to be a relation between the angiotensinogen gene and hypertension associated with pregnancy. ${ }^{20} 21$

The angiotensinogen gene may be of more general cardiovascular importance. Two recent reports, which used a Japanese ${ }^{22}$ and Caucasian $^{23}$ patient population respectively, found that particular molecular variants of the angiotensinogen gene are found more commonly in patients with coronary atherosclerosis and myocardial infarction than in control subjects.

\section{THE ACE GENE}

DNA variation in the ACE gene is demonstrable by polymerase chain reaction (PCR) as the presence or absence of a small stretch of DNA that defines the insertion $(I)$ or deletion $(D)$ variants (alleles) respectively. ${ }^{24}$ The $D$ allele is associated with higher levels of ACE in plasma $^{25}{ }^{26}$ and lymphocytes, ${ }^{27}$ suggesting some genetic programming of the renin-angiotensin system. This does not appear to be the result of the DNA deletion per se, which probably serves as a marker for an adjacent mutation that affects ACE activity. Individuals carrying 
The three ACE genotypes

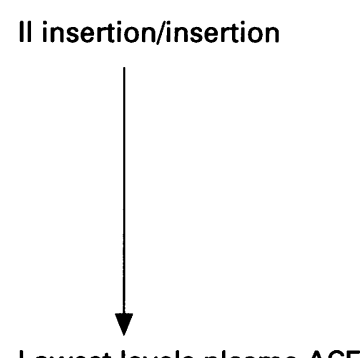

Lowest levels plasma ACE
ID

DD deletion/deletion

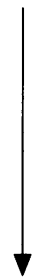

Highest levels plasma ACE

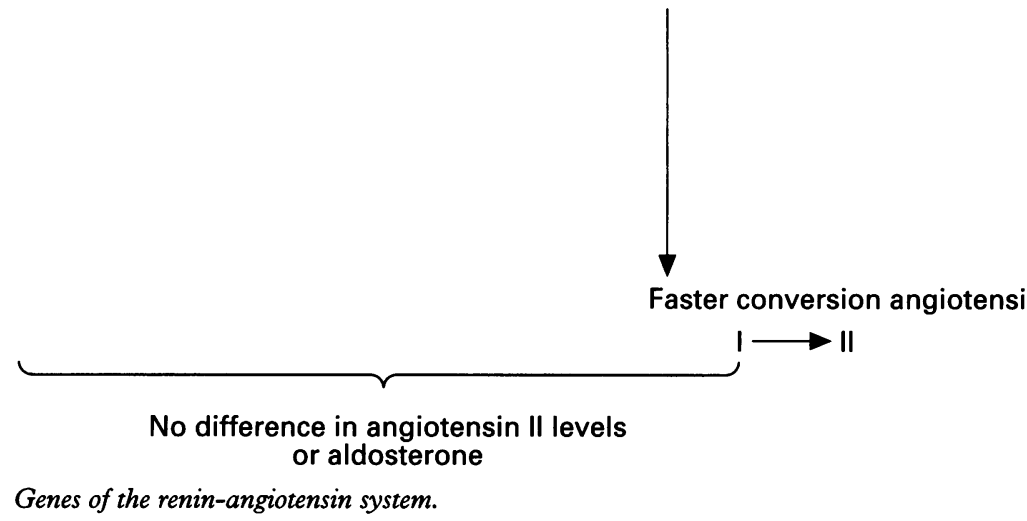

two copies of the $D$ allele ( $D D$ genotype) appear to have faster ${ }^{28}$ conversion of angiotensin I to angiotensin II. However, ACE is not believed to be the rate limiting enzyme in the renin angiotensin cascade, and the $I / D$ polymorphism appears not to influence plasma angiotensin II or aldosterone. ${ }^{26}$

There appears to be no relation between the ACE $I / D$ gene polymorphism and blood pressure. ${ }^{26}{ }^{29}$ However, Cambien and colleagues reported that the $D D$ genotype was more frequent in male Caucasian subjects with myocardial infarction (32\%) than controls $(27 \%) .{ }^{30}$ One Japanese study corroborated this association, reporting a $D D$ frequency of $42 \%$ in cases $v 16 \%$ in controls. ${ }^{31}$ Several other attempts to link the $D D$ genotype and myocardial infarction have been unsuccessful. ${ }^{32-34}$ Even in the original report, ${ }^{30}$ the magnitude of the association between the $D D$ genotype and myocardial infarction varied considerably between the four collaborating centres, some reporting no relation.

The ACE gene has attracted a great deal of attention since it was reported to be more frequent in subjects with electrocardiographic evidence of left ventricular hypertrophy. ${ }^{35}$ The $D$ allele has also been implicated in cardiac dilatation in familial cardiomyopathy and after myocardial infarction, ${ }^{36}{ }^{37}$ sudden death in cardiomyopathy, ${ }^{38}$ coronary artery stenosis after angioplasty, ${ }^{39}$ and in cardiovascular complications in diabetes. ${ }^{40}$ However, negative findings have also been reported for echocardiographic evidence of left ventricular hypertrophy ${ }^{41}$ and dilated cardiomyopathy. ${ }^{42}$

THE ANGIOTENSIN TYPE 1 RECEPTOR GENE This candidate has received attention recently. Some studies have shown a relation with hypertension, but there have been discrepan- cies between family and case-controlled approaches. ${ }^{43}$ The available receptor gene markers do not appear to show linkage to myocardial infarction. ${ }^{44}$ They have, however, been used in one study to subgroup individuals with the ACE $D$ allele in a way that appeared to discriminate better the association between the ACE gene and myocardial infarction. ${ }^{44}$

\section{Inconsistency}

Inconsistency and irreproducibility are recurring themes of molecular genetics. It is also true of genetic analysis of the reninangiotensin system in cardiovascular disease. Many readers, having grasped a basic understanding of the technology of molecular biology and the potential for genetics, are starting to develop a certain scepticism. Can we explain the inconsistencies between studies, and what are the implications for our future practice? Differences in populations, the manner in which they are sampled, the characterisation of phenotypes, the nature of the genetic markers, and publication bias may all be relevant.

\section{POPULATION EFFECTS}

Populations differ in genes and environment. ${ }^{45}$ Migration effects and changes in coronary disease rates in stable populations over time reflect environmental influences. Inherited predisposition to coronary disease may not be expressed in very good (for example, healthy lifestyles) or very bad (for example, premature death from infectious disease) environments. Thus the difference between the French and Irish components of the ECTIM study ${ }^{30}$ may be related to important differences in lifestyle. ${ }^{46}$ It was only in the French, whose age adjusted mortality for coronary heart disease is one quarter that of the Irish, that a link between the ACE $D D$ genotype and myocardial infarction could be demonstrated.

Population genetic differences may also be relevant. Cross-population comparisons show that there are important differences in the frequency of particular genetic markers, including those of the renin-angiotensin system. ${ }^{47} 48$ Contrasting genetic backgrounds have both quantitative and qualitative ramifications that may explain discrepancies in the literature. For example, the ACE gene $D D$ genotype is found in only $2 \%$ of Samoans, but as many as $42 \%$ of Caucasians. ${ }^{48}$ The angiotensinogen $T T$ genotype is found in $70 \%$ of African Americans, but only $17 \%$ of white Americans. ${ }^{19}$ Therefore, the variation between racial groups is greater than that reported in case-control comparisons of cardiovascular disease. Careful matching according to racial and population factors is important to minimise potential bias.

It is also possible that through evolutionary divergence a particular marker may no longer flag the presence of a mutation causing disease. This can occur if a marker and the mutation part company during chromosomal recombination at each generation. Different markers may be relevant in different populations. ${ }^{49}$ 
Whether genetic or environmental, if population differences explain the observed inconsistencies, it is unwise to extrapolate the results from one community to another unless there is some evidence of uniformity across different groups.

\section{POPULATION SAMPLING}

To demonstrate linkage between a genetic marker (and the surrounding stretches of chromosome) and cardiovascular disease, it is necessary to study inheritance in families. Traditional multigenerational pedigree studies are difficult for conditions such as myocardial infarction which do not declare themselves until later in life. New methods using affected pairs of relatives are gaining favour but demand considerable expertise, time, and resources.

The most convenient sampling is the casecontrol study in which the frequency of a particular genetic marker is compared between two groups. Although not a strict test of inheritance, case-control studies are the ultimate test of the usefulness of genetic markers in the broader community. ${ }^{50}$ The statistical association between a marker and disease often rests on relatively small differences in the proportion of cases and controls with the marker. But statistical significance does not necessarily equate with biological significance. Uncontrolled influences of racial or environmental factors may cause significant bias. Spurious differences may be created and important differences obscured unless particular care is taken in sampling. It is not justifiable, either scientifically or ethically, to use blood stored for some other purpose as "control data".

Case-control studies have other limitations. For example, findings in 55 year old survivors of myocardial infarction tell us nothing about those who did not make it. As an explanation of increased numbers of myocardial infarction survivors with the ACE DD genotype, ${ }^{30}$ it is plausible that individuals with the ACE II genotype are predisposed to sudden death following coronary occlusion, artificially inflating the proportion of surviving cases with the $D D$ genotype. Alternatively, the $D D$ genotype might provide a non-specific protective effect against death rather than predisposition to ischaemic heart disease. The increased prevalence of the $D D$ genotype in centenarians might support such a hypothesis. ${ }^{51}$ These possibilities are not discernable in cross sectional studies and require prospective research.

\section{PHENOTYPE CHARACTERISATION}

Inconsistency in genetic analysis may arise unless phenotypes are comparable. Phenotypes should be clinically relevant and measurable using standard criteria. For example, we cannot assume that all manifestations of coronary artery disease are the same. Atherosclerotic luminal narrowing on coronary angiography may not share the same genetic origins as myocardial infarction, which involves an interaction between thrombosis and atherosclerosis. The genetics of sudden coronary death may not mirror those of uncomplicated myocardial infarction. Genes associated with very high blood pressure ${ }^{13}$ may not necessarily be relevant to the more common clinical conditions of mild or moderate hypertension. Cardiac hypertrophy on electrocardiography ${ }^{35}$ defines a different group to that based on echocardiography. ${ }^{41}$

SUBGROUP ANALYSIS

Given the phenotypic diversity, do subgroups exist in which more precise genetic links can be defined? In the first study of the ACE gene and myocardial infarction, ${ }^{30}$ cases and controls were separated by body mass index, apolipoprotein B, and lipid lowering therapy into "high" and "low" coronary risk groups. The association between the $D D$ genotype and myocardial infarction existed only in the low group. ${ }^{30}$ That the $D D$ genotype should be detrimental only in the absence of other risk factors is unusual. ${ }^{52}$ The significance of this finding is also uncertain because the idiosyncratic "high/low" definition resulted in $74 \%$ of the controls categorised as "high" risk.

Subgrouping has also been based on molecular analysis. The combination of the $D D$ genotype of the ACE gene and the $C$ variant of the angiotensin type 1 receptor gene $\left(\mathrm{AT}_{1} / C\right)$ appeared to be more closely associated with myocardial infarction than either variant alone, although the $\mathrm{AT}_{1} / C$ was not itself associated with myocardial infarction. ${ }^{44}$

Attempts to define subgroups are understandable, but a note of caution is required. Unless subgroups are postulated a priori, their discovery may owe more to random variation than biology and only serves to generate rather than test hypotheses. Furthermore, subgrouping may be a case of diminishing returns. To be useful, genetic markers must not be so rare that screening becomes inefficient, nor so common that they are found in most people. Of 613 cases of myocardial infarction, ${ }^{30}$ the highlighted combinations of the $\mathrm{ACE} / D D$ genotype with "low" risk, and the $A C E / D D$ genotype with the $\mathrm{AT}_{1} / C$ genotype comprised only $6 \%$ and $2 \%$ of cases respectively. ${ }^{3044}$ The combination of the ACE/DD genotype and at least one $C$ allele of the $\mathrm{AT}_{1}$ gene was slightly more common, present in $18 \%$ of cases. However, it was also found in $13 \%$ of controls. As controls are at least twice as common as cases, a study of the general community would find this genetic duo more frequently associated with controls than cases. Such a combination would not really assist the practising physician to predict coronary risk. The expectations raised by terms such as "potent" risk factor do not seem to be justified. ${ }^{30}$

\section{GENETIC MARKERS}

It is easy to overlook the fact that molecular markers of the ACE, angiotensinogen, and angiotensin receptor genes are simply flags on the respective chromosomes. Disease mutations may be some distance from markers, even in adjacent genes that serve quite different functions independent of the reninangiotensin system. The ability to resolve the 
fine molecular details and pinpoint disease mutations is often very difficult. There is a need to complement the molecular approach to define the biochemical and physiological steps involving the renin-angiotensin system between DNA and disease. ${ }^{27}$ This not only strengthens the genetic case, but also provides new strategies for prevention and treatment.

\section{PUBLICATION BIAS}

It is not difficult to understand the reluctance of editors to publish negative studies. Because five out of 100 studies will produce a "statistically significant" result by chance alone, we must also foster the publication of studies that test rather than generate genetic hypotheses. Reproducibility both within and between populations has critical implications for our future practice.

\section{Conclusion}

Cardiovascular disease is of enormous public health importance. The potential magnitude and cost of genetic screening using markers of the renin-angiotensin system or other genes demand clear justification of the genetic approach. Resolving and understanding the inconsistency in the existing literature is an important step towards the time when we may include DNA analysis with blood pressure and cholesterol screening as part of a routine cardiovascular assessment, or fashion prevention and treatment on the basis of genotype.

1 Dzau VJ. Circulating versus local renin-angiotensin system 1988;77:4-13.

2 Harrap SB, Dominiczak AF, Fraser R, Lever AF, Foy CJ, Watt GCM. Plasma angiotensin II, predisposition to hypertension and left ventricular size in healthy young adults. Circulation 1996;93:1148-54.

3 Dahlöf B, Pennert K, Hansson L. Reversal of left ventricular hypertrophy in hypertensive patients. A meta-analysis of 109 treatment studies. Am f Hypertens 1992;5:95-110.

4 Simoons ML. Myocardial infarction: ACE inhibitors for all? For ever? Lancet 1994;344:279-81.

5 The SOLVD Investigators. Effect of enalapril on survival in patients with reduced left ventricular ejection fractions patients with reduced left ventricular ejection fractions and congesti

6 O'Dell SD, Humphries SE, Day IN. Rapid methods for population-scale analysis for gene polymorphisms: the ACE gene as an example. Br Heart f 1995;73:368-71.

7 Harrap SB, Watt GC. Genetics and the risk of coronary heart disease. Med f Aust 1992;156:594-6.

8 Harrap SB. Genetics of coronary disease: beginning the long journey [comment]. Lancet 1994;344:901-2.

9 Naftilan AJ, Williams R, Burt D, Paul M, Pratt RE, Hobart $P$, et al. A lack of genetic linkage of renin gene restriction fragment length polymorphisms with human hypertension. Hypertension 1989;14:614-8.

10 Jeunemaitre X, Rigat B, Charru A, Houot AM, Soubrier F, Corvol, P. Sib pair linkage analysis of renin gene haplotypes in human essential hypertension. Hum Genet 1992;88:301-6.

11 West MJ, Summers KM, Burstow DJ, Wong KK, Huggard PR. Renin and angiotensin-converting enzyme genotypes in patients with essential hypertension and left ventricular hypertrophy. Clin Exp Pharmacol Physiol 1994;21: 207-10.

12 Watt GC, Harrap SB, Foy CJ, Holton DW, Edwards HV, Davidson HR, et al. Abnormalities of glucocorticoid metabolism and the renin-angiotensin system: a four-corners approach to the identification of genetic determiners approach to the identification of genetic determ
nants of blood pressure. $₹$ Hypertens 1992;10:473-82.

13 Jeunemaitre X, Soubrier F, Kotelevtsev YV, Lifton RP, Williams CS, Charru A, et al. Molecular basis of human Williams CS, Charru A, et al. Molecular basis of human
hypertension: role of angiotensinogen. Cell 1992;71: hyperten

14 Caulfield M, Lavender P, Farrall M, Munroe P, Lawson M, Turner $P$, et al. Linkage of the angiotensinogen gene to

15 Hata A, Namikawa C, Sasaki M, Sato K, Nakamura T, Tamura $\mathrm{K}$, et al. Angiotensinogen as a risk factor for essential hy

16 Iwai N, Ohmichi N, Nakamura Y, Mitsunami K, Kinoshita
M. Molecular variants of the angiotensinogen gene and hypertension in a Japanese population. Hypertens Res 1994;17:117-21.

17 Hegele RA, Brunt JH, Connelly PW. A polymorphism of the angiotensinogen gene associated with variation in blood pressure in a genetic isolate. Circulation 1994;90: 2207-12.

18 Barley J, Blackwood A, Sagnella G, Markandu N, MacGregor G, Carter N. Angiotensinogen Met235 Thr polymorphism in a London normotensive and hypertenpolymorphism in a black and white population. $\mathcal{f}$ Hum Hypertens 1994;8:639-40.

19 Rotimi C, Morrison L, Cooper R, Oyejide C, Effiong E, Lapido M, et al. Angiotensinogen gene in human hypertension. Lack of an association of the 235T allele among African Americans. Hypertension 1994;24:591-4.

20 Ward K, Hata A, Jeunemaitre X, Helin C, Nelson L, Namikawa C, et al. A molecular variant of angiotensinogen associated with preeclampsia. Nat Genet 1993;4: 59-61.

21 Arngrimsson R, Purandare S, Connor M, Walker JJ, Bjornsson S, Soubrier F, et al. Angiotensinogen: a candidate gene involved in preeclampsia? [letter, comment]. Nat Genet 1993;4:114-5.

22 Ishigami $T$, Umemura $S$, Iwamoto $T$, Tamura $K$, Hibi $K$, Yamaguchi $\mathrm{S}$, et al. Molecular variant of angiotensinogen gene is associated with coronary atherosclerosis. Circulation 1995;91:951-4.

23 Katsuya T, Koike G, Yee TW, Sharpe N, Jackson R, Norton $\mathrm{R}$, et al. Association of angiotensinogen gene T235 variant with increased risk of coronary heart disease. Lancet 1995;345:1600-3.

24 Rigat B, Hubert C, Corvol P, Soubrier F. PCR detection of the insertion/deletion polymorphism of the human angiotensin converting enzyme gene (DCP1) (dipeptidyl carboxypeptidase 1). Nucleic Acids Res 1992;20:1433.

25 Rigat B, Hubert C, Alhenc-Gelas F, Cambien F, Corvol P, Soubrier F. An insertion/deletion polymorphism in the angiotensin I-converting enzyme gene accounting for half angiotensin I-converting enzyme gene accounting for half
the variance of serum enzyme levels. $f$ Clin Invest 1990 ; the variance

26 Harrap SB, Davidson HR, Connor JM, Soubrier F, Corvol $\mathrm{P}$, Fraser $\mathrm{R}$, et al. The angiotensin I converting enzyme gene and predisposition to high blood pressure. Hypertension 1993;21:455-60.

27 Costerousse O, Allegrini J, Lopez M, Alhenc-Gelas F. Angiotensin I-converting enzyme in human circulating mononuclear cells: genetic polymorphism of expression in T-lymphocytes. Biochem $\mathcal{f}$ 1993;290:33-40.

28 Ueda S, Elliott HL, Morton JJ, Connell JMC. Enhanced pressor response to angiotensin $I$ in normotensive men with the deletion genotype (DD) for angiotensin-converting enzyme. Hypertension 1995;25:1266-9.

29 Jeunemaitre X, Lifton RP, Hunt SC, Williams RR, Lalouel JM. Absence of linkage between the angiotensin converting enzyme locus and human essential hypertension. Nat Genet 1992;1:72-5.

30 Cambien F, Poirier O, Lecerf L, Evans A, Cambou JP, Arveiler D, et al. Deletion polymorphism in the gene for angiotensin-converting enzyme is a potent risk factor for myocardial infarction. Nature 1992;359:641-4.

31 Zhao Y, Higashimori K, Higaki J, Kamitani A, Ohishi M, Katsuya $\mathrm{T}$, et al. Significance of the deletion polymorphism of the angiotensin converting enzyme gene as a phism of the angiotensin converting enzyme gene as a Hypertens Res 1994;17:55-7.

32 Bohn M, Berge KE, Bakken A, Erikssen J, Berg K. Insertion/deletion (I/D) polymorphism at the locus for Insertion/deletion (I/D) polymorphism at the locus for tion. Clin Genet 1993;44:292-7.

33 Lindpaintner K, Pfeffer MA, Kreutz R, Stampfer MJ, Grodstein F, LaMotte F, et al. A prospective evaluation of an angiotensin-converting-enzyme gene polymorphism and the risk of ischemic heart disease. $N$ Engl $\mathscr{f} \mathrm{Med}$ 1995;332:706-11.

34 Miettinen HE, Korpela K, Hamalainen L, Kontula K. Polymorphisms of the apolipoprotein and angiotensin converting enzyme genes in young North Karelian patients with coronary heart disease. Hum Genet 1994;94: 189-92.

35 Schunkert H, Hense HW, Holmer SR, Stender M, Perz S, Keil U, et al. Association between a deletion polymorphism of the angiotensin-converting-enzyme gene and left ventricular hypertrophy. $N$ Engl $f$ Med 1994;330: $1634-8$.

36 Raynolds MV, Bristow MR, Bush EW, Abraham WT, Lowes BD, Zisman LS, et al. Angiotensin-converting enzyme DD genotype in patients with ischaemic or idiopathic dilated cardiomyopathy. Lancet 1993:342:1073-5.

37 Pinto YM, van Gilst WH, Kingma JH, Schunkert H. Captopril and Thrombolysis Study Investigators. Captopril and Thrombolysis Study Investigators. Deletion-type allele of the angiotensin-converting enzyme gene is associated with progressive ventricular dilation after anterior myo
Cardiol 1995;25:1622-6.

38 Marian AJ, Yu QT, Workman R, Greve G, Roberts R. Angiotensin-converting enzyme polymorphism in hyperAngiotensin-converting enzyme polymorphism in hypertrophic cardiomyopathy
Lancet 1993;342:1085-6.

39 Ohishi M, Fujii K, Minamino T, Higaki J, Kamitani A, Rakugi $\mathrm{H}$, et al. A potent genetic risk factor for restenosis [letter]. Nat Genet 1993;5:324-5.

40 Ruiz J, Blanché H, Cohen N, Velho G, Cambien F, Cohen $\mathrm{D}$, et al. Insertion/deletion polymorphism of the 
angiotensin-converting enzyme gene is strongly associated with coronary heart disease in non-insulin-dependent diabetes mellitus. Proc Natl Acad Sci USA 1994

Kupari M, Perola M, Koskinen P, Virolainen J, Karhunen PJ. Left ventricular size, mass, and function in relation to angiotensin-converting enzyme gene polymorphism in angiotensin-converting enzyme gene polym
humans. Am $\mathcal{F}$ Physiol 1994;267:H1107-11.

42 Montgomery HE, Keeling PJ, Goldman JH, Humphries SE, Talmud PJ, McKenna WJ. Lack of association between the insertion/deletion polymorphism of the angiotensin-converting enzyme gene and idiopathic dilated cardiomyopathy. $\mathcal{F} \mathrm{Am}$ Coll Cardiol 1995;25 1627-31.

43 Bonnardeaux A, Davies E, Jeunemaitre X, Fery I, Charru A, Clauser E, et al. Angiotensin II type 1 receptor gene polymorphisms in human essential hypertension. Hypertension 1994;24:63-9.

44 Tiret L, Bonnardeaux A, Poirier O, Ricard S, MarquesVidal P, Evans A, et al. Synergistic effects of angiotensinconverting enzyme and angiotensin-II type 1 recepto gene polymorphisms on risk of myocardial infarction.
Lancet 1994;344:910-3.

45 Harrap SB. Hypertension: genes versus environment. Lancet 1994;344:169-71.

46 Criqui MH, Ringel BL. Does diet or alcohol explain the French paradox? Lancet 1994;344:719-23.

47 Lee EJ. Population genetics of the angiotensin-converting enzyme in Chinese. Br f Clin Pharmacol 1994;37:212-4. 48 Johanning GL, Johnston KE, Tamura T, Goldenberg RL. Ethnic differences in angiotensin converting enzyme gene Ethnic differences in angiotensin converting enzym
polymorphism [letter]. $\mathscr{F}$ Hypertens 1995;13:710-1.

49 Doria A, Warram JH, Rich SS, Krolewski AS. Angiotensin Iconverting enzyme (ACE): estimation of DNA haplotypes in unrelated individuals using denaturing gradien gel blots. Hum Genet 1994;94:117-23.

50 Harrap SB. Public health, cardiovascular disease and molecular biology. Kidney Int 1994;46:1546-9.

51 Schachter F, Faure-Delanef L, Guenon F, Rouger H, Froguel P, Lesueur-Ginot L, et al. Genetic associations with human longevity at the APOE and ACE loci. Nat Genet 1994;6:29-32.

52 Swales JD. ACE gene: the plot thickens [comment]. Lancet 1993;342:1065-6. 